\title{
リアクタンス特性と集団主義・独自性・説得効果の関係
}

\section{北海道教育大学 今城周造}

Reactance proneness, collectivism, uniqueness, and resistance to persuasion

Shuzo Imajo (Hokkaido University of Education, Hachiman-cho, Hakodate 040-8567)

This study examined the reliability and validity of Japanese psychological reactance scales. A total of 167 undergraduates completed a questionnaire of Therapeutic Reactance Scale (TRS), the Hong Reactance Scale (HRS), the Uniqueness Scale, and the Collectivism Scale. They also received messages involving three persuasion situations that were either high or low in terms of threat, and were asked to describe their reactions to them. The author categorized the reactions into three: acceptance, indirect resistance, and direct resistance. Reliabilities of the reactance scales were satisfactory. Their scores positively correlated with uniqueness scores, and negatively with collectivism scores. Those high on reactance proneness were less persuaded in two of the three situations. But in the third, an HRS by threat interaction was observed, indicating that only those who were high on reactance proneness under the high-threat condition showed resistance to persuasion. These results suggest that the Japanese versions of reactance scale were reliable and valid. However, the assertiveness aspect of TRS may not be appropriate for the definition of reactance. The influence of culture on psychological reactance was also discussed.

Key words: reactance, uniqueness, collectivism, culture, resistance to persuasion.

本研究の目的は，二つのリアクタンス尺度（Dowd， Milne, \& Wise, 1991; Hong \& Page, 1989) の信頼性と 妥当性を比較・検討することである.その際，文化的 要因や説得効果との関係に焦点を当てる.

心理的リアクタンスとは“自由が侵害されたときに その回復を目指す動機づけ”である（Brehm＆ Brehm，1981）。禁止や強制，高圧的説得はどれも自由 を夰かすので，人はそれに抵抗し，自由を回復しよう とする。この予測を支持する報告もあるが (e.g. Snyder \& Wicklund, 1976), 高圧的説得に対して抵抗 が生じなかった報告も少なくない（e.g.上野, 1986).

その理由としては，リアクタンスに関する個人差が 挙げられる。Merz（1983）はリアクタンスの生じや すさの程度自体をパーソナリティ特性ととらえ，リア クタンス特性を測定する 18 項目のドイツ語による尺 度を作成した。Tucker \& Byers（1987）はこの Merz 尺度を英語に翻訳したが，因子的妥当性が不十分で実 用に耐えないと結論づけている．Hong らは後にこの 英語版 Merz 尺度を改良して, Hongリアクタンス尺 度を開発した（Hong \& Faedda, 1996; Hong \& Page, 1989).

一方これらの Merz 尺度に端を発する研究とは別 に, Dowd et al. (1991) は治療リアクタンス尺度 （TRS）を作成している。しかしその内容は“意見を
闘わせるのはおもしろい”など，自由回復の動機づけ とは関係ないものも含んでおり,リアクタンスという 構成概念と TRS の対応には疑問が残る。

ところで今城（2001）は，リアクタンスの個人差だ けでなく，その文化差を検討する必要があることを指 摘している.リアクタンス理論では行動の自由は前提 であり，諸個人が自由を期待しているからこそ，自由 侵害に対する自由回復行動の生起は一般的な法則性を もつ.しかし人々の大多数が自由を期待していること を，我が国でも前提にできるだろうか，Kim， Triandis, Kagitcibasi, Choi, \& Yoon (1994) によれ ば，西洋の個人主義文化では，人は自律的・自己支配 的・独自的であるように，また選択の自由を価值づけ るように仕向けられる。一方，東洋の集団主義文化で は, 個人主義的欲求は抑圧され, 相互依存と承諾が重 要とされる。このように,リアクタンス理論が前提と する自由や自己支配が個人主義と表裏一体であるなら ば，我が国を含む集団主義文化では，リアクタンス現 象が生起する可能性は低いことになる。

Yamaguchi（1994）は，日本人には集団主義傾向が 強いこと, 集団主義傾向は独自性欲求（Snyder＆ Fromkin, 1977）を弱めることを指摘している. 独自 性欲求とリアクタンスの関連については上野（1986） が実験的検討を試みたが，分散分析の結果では，意見 変化に有意な要因効果は見られなかった。本研究で 
は，リアクタンス特性と集団主義・独自性欲求の関係 を調べることで，リアクタンスの文化差を考察する.

本研究の仮説は次のとおりであった：リアクタンス 特性が強いほど, 説得に抵抗するであろう（仮説 1). 集団主義傾向が強いほど，リアクタンス特性は弱 いであろう（仮説 2). 独自性欲求が強いほど, リア クタンス特性も強いであろう（仮説 3 ).

\section{方 法}

被験者 被験者は大学生 167 人（男 79 ，女 88 ）で あった。

手続き 心理学の授業時間中に集団実施した，質問 紙の前半は 14 項目の Hong リアクタンス尺度（Hong \& Page, 1989)，28 項目の治療リアクタンス尺度 （Dowd et al., 1991），24 項目の独自性尺度（山岡， 1993)，10 項目の集団主義尺度（山口・岡・丸岡・渡 辺・渡辺，1988）であった（“全くあてはまらない1 一非常によくあてはまる5”の 5 件法).

次に被験者は, 説得場面についての自由記述を求め られる。これは深田（1983）と同様の方法であり, 説 得場面の略画（Figure 1) では, 他者からの説得に対 する主人公の台詞が空欄の吹き出しになっていて, 被 験者は自分ならどう答えるかを考え, 空闌に書くよう に指示される。場面には 3 種類あり, 被験者はそのい ずれにも記入する.息子が母親から部屋を掃除するよ うに言われる場面は，私的空間への介入であり最も抵 抗が生じやすい. 学校に携帯電話を持ってこないよう に教官から言われる場面は, 公的空間での規範遵守要 請であり抵抗は生じにくくなる. 一方, 友人から街頭 募金を促される場面では, その遂行には選択の余地が あり，個人差が出やすいであろう.

さらに他者の発言の表現を変えることで, 自由への 脅威操作を行った。説得には脅威小（募金の例 “あそ
こで募金をしているね.僕たちも募金しょうか.”）と 脅威大 (“あそこで募金をしているね. 君も募金をす べきだと思うよ.”）の 2 種類があり，被験者はそのど ちらかを読んだ。脅威大条件では説得の圧力が大き く, 行動の自由が脅かされる.

自由記述は 3 人の評定者が独立に“受容（言われた とおりにする)” “間接的拒否（拒否を明言せず，苦情 を述べたり，後回しにしたりする)”“直接的拒否（拒 否を明言し，断ったり，抗議して従わない)”の 3 力 テゴリーに分類し，それぞれ 3 点， 2 点， 1 点と得点 化した。これが説得効果の指標となり，数值が小さい ほどリアクタンスの影響を意味する。

\section{結果と考察}

\section{Hong 尺度}

Hong 尺度（信頼性係数 $\alpha=.84 ）$ の合計点は $M=$ $40.35, S D=7.91$ であった。次にHong 尺度の因子構 造を検討した。重みづけのない最小 2 乗法で因子を抽 出し, プロマックス回転 (斜交解) を行った。因子負 荷量が.4 以上の項目に注目し, 先行研究を参考に因 子を命名した．ただし，他の因子にも同程度の重みが ある項目は除外した. Hong 尺度ではスクリープロッ 卜の結果から 3 因子解を採用した（Table 1). 第 1 因 子は項目 1，3，2，13 亿負荷が高く，“逆らうこと” “承諾一非承諾”に関係しているので “承諾へのリア クタンス” 因子と命名した。第 2 因子は項目 10,5 , 9, 12 に負荷が高く, 他者からの助言, 影響への反発 にかかわるので “助言・影響への抵抗” 因子とした。 また第 3 因子は項目 6，7，8，4 亿負荷が高く，不快 な感情が共通しているので “選択制限への情動反応” 因子と命名した。因子間相関はどれも中程度の正の值 を示している。

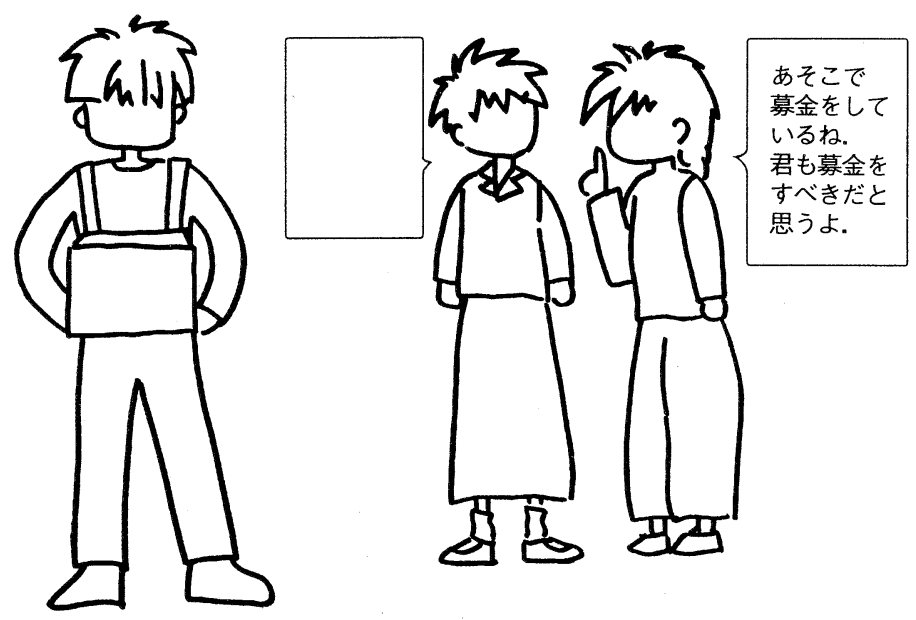

Figure 1. “街頭募金”場面の略画例. 
Table 1

Hong リアクタンス尺度の因子分析

\begin{tabular}{|c|c|c|c|c|}
\hline & 質問項目 & 因子 1 & 因子 2 & 因子 3 \\
\hline 1 & 規則というものがあると，反抗心がムラムラとわいてくる. & .881 & -.152 & .006 \\
\hline 3 & $\begin{array}{l}\text { あることを禁じられると, “それこそが自分のやろうとしているものだ”と思うこ } \\
\text { とがよくある. }\end{array}$ & .612 & -.125 & .147 \\
\hline 2 & 人の意見に逆らうのは気分がいい。 & .466 & .274 & -.079 \\
\hline 13 & あることをむりやりさせられそうになると, その逆のことをしたくなる. & .457 & .260 & -.061 \\
\hline 14 & 人が社会の基準や規範に従わされているのを目にするとがっかりする。 & .345 & -.119 & .120 \\
\hline 10 & 自分の自由な意志で行動しているときだけ, 満ち足りた気持ちがする. & -.284 & .597 & .239 \\
\hline 5 & 助言というのは押しつけだと思う。 & -.080 & .584 & .096 \\
\hline 9 & 助言や勧告をされると，それとまったく逆の行動をすることになってしまう. & .349 & .521 & -.106 \\
\hline 12 & 見習うべき手本としてほかの人を引き合いに出されると，ムカッとする. & -.022 & .418 & -.116 \\
\hline 11 & 人が自分にあれこれさせようとしたら逆らう。 & .342 & .394 & .107 \\
\hline 6 & ものごとを自分なりに自由に決められないと欲求不満に陥る。 & -.044 & -.008 & .588 \\
\hline 7 & 言われなくてもわかっていることを，人から指摘されるといらいらする. & .184 & -.106 & .534 \\
\hline 8 & 選択の自由を制限されるとムカッとする. & .010 & .068 & .515 \\
\hline 4 & 人の言いなりになることを考えるとしゃくにさわる. & .206 & .065 & .464 \\
\hline \multirow{2}{*}{\multicolumn{2}{|c|}{ 因子間相関 }} & 一 & .650 & .563 \\
\hline & & & - & .604 \\
\hline
\end{tabular}

Hong \& Faedda（1996）は Hong 尺度が 4 因子から なることを報告しているが, 彼らの “選択制限への情 動反応 $(6 ， 8 ， 7 ， 4)$ ” 因子は, 本研究の第 3 因子に 対応している。一方, Hong \& Faedda（1996）の“他 者加ら影響への抵抗 $(11,12,13,10,14)$ ” 因子 は一つにまとまらず, 本研究では他の 2 因子に分散し た.この “他者・抵抗”と Hong \& Faedda（1996） の “助言と勧告へのリアクタンス $(5,9) ”$ が結合し たものが本研究の第 2 因子である. また本研究の第 1 因子は，Hong \& Faedda（1996）の“承諾へのリアク タンス因子 (項目 1，3，2）”に“他者・抵抗”が加 わった内容である.つまり本研究の結果は, Hong \& Faedda（1996）のものとほぼ対応しているが, 1 因子 少ない.

しかし Hong \& Faedda（1996）の“助言と勧告へ のリアクタンス”は，主成分法で抽出された 2 変数か らなる因子であり，因子としての安定性は低いと考え られる.小口・岡田（1999）の翻訳によるHong 尺度 でも，本研究とほぼ対応する 3 因子が主因子法により 抽出されている.したがって Hong 尺度は, 本研究の 因子順に記せば“強制への反抗”“干渉への反発”“情 動反応”を内容とする 3 因子からなるとした方が適当 であろう。

\section{TRS}

TRS $(\alpha=.78)$ の合計点は $M=81.72, S D=10.46$
に高かった(平均值は男子で 83.78, 女子で 79.88; $t(165)=2.45, p<.05)$.

TRS の因子分析では, スクリープロットの結果か ら 3 因子解を採用した (Table 2). 第 1 因子は項目 25，18，21，7 で負荷が大きく，同調傾向の逆転項目 なので “非同調” の因子と解釈した. 第 2 因子は項目 9，15，8，26，5 に負荷が高い。これらは自由の重視 と意見の主張に関係しており，“自由のための主張” 因子と命名した。第 3 因子は項目 10，6，2，17 に負 荷が高く，内容を問わず他者に逆らう“反抗”因子と 解釈した。因子間相関は全体に低い。

Dowd et al. (1991) は TRS を因子分析（主因子解, オブリミン回転）し，2因子解を採用している(“行 動的リアクタンス”“言語的リアクタンス”). 前者は 本研究の第 3 因子 “反抗” に, 後者は第 2 因子“自由 のための主張”にほぼ対応する（Table 2)。さらに本 研究では逆転項目が集まった“非同調”因子が抽出さ れたが，その内容は“同調性” 尺度であり，削除候補 となる。

\section{両リアクタンス尺度の関係}

Hong 尺度得点と TRS 得点の相関係数 $r$ は+.63( $p$ ＜.01）であった。両リアクタンス尺度は中程度の正 の相関を示している。

次に両リアクタンス尺度の各因子を構成する項目を 加算し，下位尺度得点を算出した。下位尺度間の相関 係数と信頼性係数 $\alpha$ を Table 3 に示す. 項目数が 4 
Table 2

治療リアクタンス尺度の因子分析（ $\mathrm{R}=$ 逆転項目）

\begin{tabular}{|c|c|c|c|c|}
\hline & 質問項目 & 因子 1 & 因子 2 & 因子 3 \\
\hline 25 & 人からの助言にはよく従う.R & .809 & -.093 & .054 \\
\hline 18 & 人が“こうしたら”と言ってくれたことによく従う. R & .805 & -.077 & -.055 \\
\hline 21 & $\begin{array}{l}\text { 私自身の問題を解決するために,ほかの人が言ってくれた考えをよく受け入れる. } \\
\mathrm{R}\end{array}$ & 649 & -.180 & .094 \\
\hline 7 & 議論をすると，すぐ説得されてしまう. R & .464 & .262 & -.278 \\
\hline 27 & とても意地っぱりで, 自分流のやり方で押しとおす. & .338 & .299 & .010 \\
\hline 28 & $\begin{array}{l}\text { まわりの人たち（仲間や同僚など）と仲良くやっていくことは，とても大切だと } \\
\text { 思う. R }\end{array}$ & .274 & -.089 & .124 \\
\hline 13 & $\begin{array}{l}\text { 仲間がほかのことをやりたいと言うので, 自分の計画を変更することになっても, } \\
\text { いらついたりしない. R }\end{array}$ & .235 & -.122 & .150 \\
\hline 24 & 理由ははっきりしなくても，人のために何かをすることは苦にならない. R & .213 & -.068 & .086 \\
\hline 16 & 頼みごとをされると，その人の本当のねらいが何なのか，ょく考える. & .174 & -.076 & -.023 \\
\hline 9 & 仕事や勉強で, 自分がしたいと思っていることをもっと自由にやりたい. & -.204 & .654 & -.031 \\
\hline 15 & 意見を闘わせるのはおもしろい. & -.127 & .599 & .032 \\
\hline 8 & 議論が盛り上がってくると，我を忘れて熱中してしまう。 & -.168 & .557 & .063 \\
\hline 26 & 黙ったままでいるよりは, 信ずるところに従って意見を述べる方がいい. & -.007 & .495 & -.121 \\
\hline 5 & 私個人の自由は大切にしていきたいと心から思っている。 & -.113 & .469 & -.036 \\
\hline 11 & 恐くて人の意見に反対できないことがときどきある. R & .374 & .400 & -.218 \\
\hline 1 & 出てきた料理が冷めていたら, 店の人にそのことで注意する. & .028 & .354 & .058 \\
\hline 20 & 影響力の強い地位につくことは大切だと思う。 & -.182 & .316 & .240 \\
\hline 19 & どちらかといえば，自分の意見の正しさを主張する方だ. & .208 & .311 & .092 \\
\hline 10 & あれこれ指図されると, その逆のことをしてしまう場合がよくある。 & .158 & -.125 & .610 \\
\hline 6 & “あまのじゃく”をするのは扔もしろい. & -.127 & -.040 & .577 \\
\hline 2 & 目上の人（教師や上司など）から，あれこれ指図されるとムカッとする. & .031 & .189 & .528 \\
\hline 17 & 人が私を説得しようとするのは，とても我慢できない. & .113 & -.099 & .515 \\
\hline 23 & 自分は協調的というよりも競争的だと思う。 & .226 & .254 & .385 \\
\hline 12 & 警官があれこれ指図するのはしゃくにさわる. & .070 & .245 & .376 \\
\hline 4 & 禁じられていることを，ほかの人がやってくれると気分がいい. & -.058 & -.114 & .304 \\
\hline 3 & 偉い人の話は，本当かどうかと疑ってしまうことがよくある. & .243 & .106 & .287 \\
\hline 22 & 自分は正しいと考えているような人たちの誤りを，人前で指摘するのは楽しい. & .008 & .085 & .201 \\
\hline 14 & あれこれ指図されるのは気にならない. R & .084 & .011 & .147 \\
\hline \multirow{2}{*}{\multicolumn{2}{|c|}{ 因子間相関 }} & - & .342 & .335 \\
\hline & & & - & .198 \\
\hline
\end{tabular}

Table 3

Hong 尺度と TRS の下位尺度間の相関係数

\begin{tabular}{lccc}
\hline \multirow{2}{*}{ Hong 尺度 } & \multicolumn{3}{c}{ TRS } \\
\cline { 2 - 4 } & 非同調 $(.71)$ & 主張 $(.67)$ & 反抗 $(.64)$ \\
\hline 承諾 $(\alpha=.73)$ & $.263^{* *}$ & $.236^{* *}$ & $.613^{* *}$ \\
助言・影響 $(.60)$ & $.229^{* *}$ & .104 & $.534^{* *}$ \\
情動反応 $(.68)$ & $.299^{* *}$ & $.370^{* *}$ & $.345^{* *}$ \\
$* * p<.01$ & & & \\
$* *$ & & &
\end{tabular}

から 5 と少ないので信頼性は十分とはいえないが, TRSの “反抗”は，Hong 尺度の“承諾”および “助 言・影響”と中程度の正の相関がある。さらにこの相 関行列を対象として階層クラスター分析（グループ内 平均連結法）を行った（Figure 2). TRS の下位尺度 のうち Hong 尺度と密接な関係があるのは“反抗”だ けであり, 特に“自由のための主張”、は Hong 尺度と は異質な内容であることが読み取れる.

リアクタンスはあくまで“自由侵害への反応”であ るから,ただ単に“主張好き”であったり, 自由拡大 のために自分から議論を巻き起こしていくのはリアク 
タンスではない.“自由のための主張”因子（TRS） では，自由を重視する内容が含まれていたからよい が，それがなければ単なる “主張性”尺度であり，リ アクタンス尺度ではなくなることに留意しなければな らない.

“自由侵害への反応”というリアクタンスの定義と 合致しない項目には，以上の “主張性・議論好き（8, $15 ， 19 ， 26)$ ” “非同 調” $(7,11 ， 13 ， 14 ， 18 ， 21$, $24 ， 25 ， 28 ）$ のほかにも, 自由侵害と関係ない項目 (1), 反応的でなく主導的な項目 $(20 ， 23 ， 27)$, 反抗 に悪意のある項目 $(6 ， 22)$ が挙げられる。これらを 除いて TRS を因子分析し，因子負荷の小さい項目を 除去していくと，反抗 $(2,12,3,10,17 ; \alpha=.67)$ と自由（9，5； $\alpha=.68 ）$ の 2 因子を得る（全 7 項目の $\alpha$ は.61). TRS の内容でリアクタンスの定義に合う のは，この“自由・反抗”の部分だけである。

結局, リアクタンス理論から見て妥当なリアクタン スの指標は, Hong 尺度全体と, TRS の “自由・反 抗”下位尺度である.TRSの “自由のための主張” 因子については, 主張や議論の目的が自由回復である ことがわかるような修正を考慮すべきであろう。

\section{リアクタンス特性と説得効果}

説得への自由記述反応を 3 人の評定者が分類したと ころ，そのうちの任意の 2 人の評定者間の一致率は $0.72-0.82$ であった. 脅威大条件の反応例を次に示 す．受容反応として“はーい”“気をつけます”“そう だね，募金しょう”。間接的拒否として“今やろうと 思ってたんだよ”“わかった。後でやるよ”“すみませ ん。でも（携帯電話は）必要なのです” “募金するよ。 でも何ですすべきななさ”“少しくらいなら募金しょ うかな”。直接的拒否として“気になるなら自分でや れ”“何でですか，別にいいと思います”“いやだよ。 募金したいなら 1 人ですれば”. 直接的拒否は, 脅威 大条件でも場面を問わず最も小さい比率であり，間接 的拒否の方が生じやすい傾向がうかがわれた（例えば 部屋掃除場面では，受容が $27.7 \%$ ，間接的拒否が 60.3 $\%$, 直接的拒否が $12.0 \%$ ).

説得への自由記述反応とリアクタンス尺度得点（各 総得点および下位尺度得点）の相関係数を計算した (Table 4). 有意な相関係数はすべて負の值であり, 説得の圧力の大小を問わず，リアクタンス特性が高い

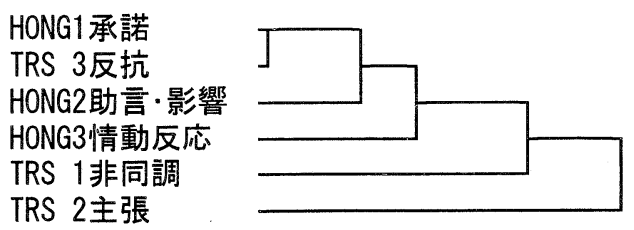

Figure 2. リアクタンス下位尺度のクラスター.
Table 4

説得効果とリアクタンス尺度得点の相関係数

\begin{tabular}{clll}
\hline & 部屋掃除 & 携帯電話 & 街頭募金 \\
\hline Hong 尺度 & $-.314^{* *}$ & $-.176^{*}$ & -.130 \\
1 承諾 & $-.313^{* *}$ & $-.166^{*}$ & -.111 \\
2 助言・影響 & $-.272^{* *}$ & -.068 & $-.179^{*}$ \\
3 情動反応 & $-.185^{*}$ & $-.195^{*}$ & -.022 \\
TRS & $-.282^{* *}$ & $-.323^{* *}$ & -.074 \\
1 非同調 & $-.242^{* *}$ & $-.198^{*}$ & -.008 \\
2 主張 & -.090 & $-.179^{*}$ & -.103 \\
3 反抗 & $-.212^{* *}$ & $-.165^{*}$ & -.064 \\
$\quad$ (自由・反抗) & $-.302^{* *}$ & $-.239^{* *}$ & -.060 \\
$* p<.05, * * p<.01$ & & &
\end{tabular}

ほど説得効果が小さいことを示している（仮説 1 はほ ぼ支持された)。

街頭募金場面ではリアクタンス総得点と説得効果の 有意な相関が見られなかったので, リアクタンス特性 と脅威操作の交互作用を検討した. Hong 尺度得点, TRS 得点のそれぞれ上位 $25 \%$ ・下位 $25 \%$ リアクタ ンス特性高群・低群とし, 説得効果得点に関するリア クタンス特性（高・低） $\times$ 脅威（大・小）の 2 要因分 散分析を行った. Hong 尺度の結果（Table 5) につ いては, 脅威の主効果と Hong 尺度 $\times$ 脅威の交互作用 が有意であった（それぞれ $F(1,77)=5.57, p<.05$; $F(1,77)=4.76, p<.05)$. また, Hong 尺度の主効果 に傾向が認められた $(F(1,77)=2.79, p<.10)$. 次 に，交互作用が有意であったので下位検定を行った。 単純主効果を見ると, Hong 尺度高群では脅威大条件 において説得効果が低く $(F(1,77)=11.81, p<$ .01)，また脅威大条件では Hong 低条件で説得効果が 高い $(F(1,77)=9.02, p<.01)$. 社会的に望ましい行 動が求められる場面では, リアクタンスは表出されに くく, 全体として承諾傾向が優勢になると考兄られ る.このような抵抗しにくい場面で抵抗できるのは, リアクタンス特性の高い人であり，しかもそれは押し つけがましく説得された場合に限られる。なお，TRS の高低による TRS $\times$ 脅威の交互作用は，傾向は Hong 尺度の場合と同様であったが，有意水準には達しなか った $(F(1,76)=1.83, p=.18)$.

一方，相関分析では脅威の大小が込みになっている が，リアクタンス特性の高い人は, 説得圧力の小さい 条件（脅威小）でも抵抗を示す可能性がある。脅威小 条件に限って同様に相関係数を算出すると, 部屋掃除 場面の説得効果は Hong 得点と一.298 $(p<.01)$, TRS 得点と $-.264(p<.05)$, 携帯電話場面の説得効 果は Hong 得点 $<-.193(p<.10)$, TRS 得点と -.352 $(p<.01)$ の相関を示した。説得が穏やかな場 
Table 5

Hong 尺度と自由への脅威が説得効果（街頭募金） に及ぼす効果

\begin{tabular}{cccc}
\hline \multirow{2}{*}{ Hong 尺度 } & & \multicolumn{2}{c}{ 自由への脅威 } \\
\cline { 3 - 4 } & & 小 & 大 \\
\hline 高 & $M$ & 2.63 & 1.96 \\
& $S D$ & $(0.50)$ & $(0.69)$ \\
& $n$ & 16 & 24 \\
低 & $M$ & 2.55 & 2.52 \\
& $S D$ & $(0.76)$ & $(0.60)$ \\
& $n$ & 20 & 21
\end{tabular}

Table 6

独自性および集団主義とリアクタンス尺度得点 の相関係数

\begin{tabular}{lcl}
\hline & 独自性 & 集団主義 \\
\hline Hong 尺度 & $.422^{* *}$ & $-.300^{* *}$ \\
1 承諾 & $.374^{* *}$ & $-.218^{* *}$ \\
2 助言・影響 & $.226^{* *}$ & $-.230^{* *}$ \\
3 情動反応 & $.416^{* *}$ & $-.267^{* *}$ \\
& & \\
TRS & $.619^{* *}$ & $-.406^{* *}$ \\
1 非同調 & $.345^{* *}$ & $-.359^{* *}$ \\
2 主張 & $.503^{* *}$ & $-.156^{*}$ \\
3 反抗 & $.287^{* *}$ & $-.245^{* *}$ \\
$\quad$ 自由・反抗 $)$ & $.462^{* *}$ & $-.286^{* *}$ \\
& & \\
${ }^{*} p<.05,{ }^{* *} p<.01$ & &
\end{tabular}

合でさえ，リアクタンス特性が高いほど説得効果が低 減するという知見は注目される。

\section{リアクタンス特性と文化的要因}

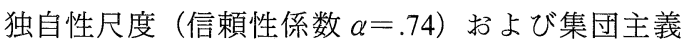
尺度（ $\alpha=.66 ）$ の各合計得点と, リアクタンス尺度得 点（各総得点および下位尺度得点）の相関係数を計算 した（Table 6). 独自性尺度はリアクタンス尺度と正 の相関関係にある (仮説 3 支持)。逆に集団主義尺度 は，リアクタンス尺度と負の相関関係にある（仮説 2 支持).なお, 独自性尺度と集団主義尺度の相関係数 $r$ は一0.27（ $p<.01 ）$ であった。

これらはリアクタンスが集団主義とは相容れず, 個 人主義と表裏一体であることを示唆している. 集団主 義文化の社会ではリアクタンス動機づけが優勢ではな く,それを顕著に示すのは個人主義的傾向の強い人だ けであろう。集団主義文化においてリアクタンスをど う位置づけるかは，今後慎重に検討すべきである．本 研究では集団主義尺度の信頼性がやや低く，また個人
主義の指標も間接的なものにとどまっている（独自性 欲求). 今後の課題としては, 個人主義と集団主義の 両方を測定できる尺度（e.g. Triandis，1995）を用い て, 個人主義・集団主義とリアクタンスとの関係をさ らに調べることが挙げられる。

\section{引用文献}

Brehm, S. S., \& Brehm, J. W. 1981 Psychological reactance: $A$ theory of freedom and control. New York: Academic Press.

Dowd, E. T., Milne, C. R., \& Wise, S. L. 1991 The therapeutic reactance scale: A measure of psychological reactance. Journal of Counseling and Development, 69, 541-545.

深田博己 1983 心理的反発に関する発達的研究 島 根大学教育学部紀要, 教育科学, 17, 31-39.

(Fukada, H. 1983 A developmental study of psychological reactance. Memoirs of the Faculty of Education, Shimane University. Educational Science, 17, 31-39.)

Hong, S.-M., \& Faedda, S. 1996 Refinement of the Hong psychological reactance scale. Educational and Psychological Measurement, 56, 173-182.

Hong, S.-M., \& Page, S. 1989 A psychological reactance scale: Development, factor structure and reliability. Psychological Reports, 64, 1323-1326.

今城周造 2001 説得におけるリアクタンス効果の研 究一一自由侵害の社会心理学—北大路書房

(Imajo, S.)

Kim, U., Triandis, H. C., Kagitcibasi, C., Choi, S., \& Yoon, G. 1994 Introduction. In U. Kim, H. C. Triandis, C. Kagitcibasi, S. Choi \& G. Yoon (Eds.), Individualism and collectivism. Thousand Oaks CA: Sage. Pp. 1-16.

Merz, J. 1983 Fragebogen zur Messung der Psychologischen Reaktanz. Diagnostica, XXIX, 7582.

小口孝司・岡田尚子 1999 リアクタンスの3 次元 昭和女子大学生活心理研究所紀要, 2, 14-31. (Oguchi, T. \& Okada, N 1999 Three fators of psychological reactance. Showa Women's University Institute of Practical Psychology Bulletin, 2, 14-31.)

Snyder, C. R., \& Fromkin, H. L. 1977 Abnormality as a positive characteristic: The development and validation of a scale measuring need for uniqueness. Journal of Abnormal Psychology, 86, 518-527.

Snyder, M. L., \& Wicklund, R. A. 1976 Prior exercise of freedom and reactance. Journal of Experimental Social Psychology, 12, 120-130.

Triandis, H. C. 1995 Individualism and collectivism. Boulder, CO: Westview Press.

Tucker, R., \& Byers, P. Y. 1987 Factorial validity of Merz's psychological reactance scale. Psychological Reports, 61, 811-815. 
上野徳美 1986 自由への脅威と受け手の独自性がリ アクタンス現象に及ぼす効果 心理学研究, 57, 228-234.

(Ueno, T. 1986 Effects of threats to attitudinal freedom and the recipient's uniqueness on psychological reactance phenomenon. Japanese Journal of Psychology, 57, 228-234.)

Yamaguchi, S. 1994 Collectivism among the Japanese: A perspective from the self. In U. Kim, H. C. Triandis, C. Kagitcibasi, S. Choi \& G. Yoon (Eds.), Individualism and collectivism. Thousand
Oaks CA: Sage. Pp. 175-188.

山口 勧 - 岡 隆 - 丸岡吉人 ・ 渡辺 聡 - 渡辺久哲 1988 合意性の推測に関する研究(I) 一一集団主義 的傾向との関連について——本社会心理学会第 29 回発表論文集, 176-177.

山岡重行 1993 ユニークネス尺度の作成と信頼性・ 妥当性の検討 社会心理学研究, 9, 181-194.

(Yamaoka, S.)

-2001.8.6 受稿, 2002.3.2 受理—— 